\title{
Exchange Rate and Capital Flows of Thailand
}

\author{
Santi Termprasertsakul and Prin Seree-amnoui
}

\begin{abstract}
The inflows and outflows of capital are important to Thailand's economy development. Since the Bank of Thailand loosens the foreign exchange regulation in 2012 together with the political instability in 2013 , the pattern of capital flows of Thailand has been changed from net capital inflows to net capital outflows. This paper revisits the impact of capital flows on real effective exchange rate of Thai Baht. We empirically investigate the impact of asymmetric capital flows on Thai Baht, using the Nonlinear Autoregressive Distributed Lags (NARDL) model to capture the asymmetry of capital flows. The monthly data of Thailand's net capital flows are investigated during 2005-2018 and decomposed into the period of capital inflows and capital outflows. The empirical evidence confirms that an increase in capital inflows causes Thai Baht to appreciate. Also, the NARDL model has an ability to identify the existence of long-run relationship between capital inflows and real effective exchange rate of Thai Baht. However, the long-run relationship between capital out flows and real effective exchange rate of Thai Baht does not exist. The model confirms the impact of asymmetric capital flows on exchange rate.
\end{abstract}

Index Terms-Capital flows, real exchange rate, asymmetry, NARDL.

\section{INTRODUCTION}

Capital flow is one of the crucial factors driving Thai economy and persuades new multinational companies (MNCs) to invest in Thailand for the past decades. Thailand has a positive capital flow balance, according to foreign direct investment (FDI) inflow, along with portfolio investment inflow during 2005-2010. However, since Bank of Thailand has set new rules to relax foreign exchange regulations in 2012, many Thai multinational companies have more opportunity to invest and doing business overseas. Additionally, the relaxation offers investment alternatives for Thai investors and allows more players to increase competition. Not only ease of regulations but also political instability in 2013, these situations has been accelerating the Thai capital outflow during 2013-2018 as shown in Fig. 1.

Such fluctuations underline the importance of revisiting the relationship between the exchange rate and capital flows of Thailand. Theoretically, the fluctuation of capital flow has influenced the exchange rates of the country. As Thailand has adopted the managed-float exchange rate regime since 1997, investors and MNCs are subject to currency risks. Under this

Manuscript received May 15, 2019; revised August 12, 2019. This research was fully supported by the Faculty of Social Sciences, Srinakharinwirot University, Bangkok, Thailand.

Santi Termprasertsakul is with Srinakharinwirot University, Bangkok, Thailand (e-mail: santit@g.swu.ac.th).

Prin Seree-amnoui is with Thammasat University, Bangkok, Thailand (e-mail: prin.seree@gmail.com). regime, the Bank of Thailand (BOT) does not target a fixed level for the exchange rate and stands ready to intervene in the case of excess volatility, particularly resulting from speculative capital flows, in a manner consistent with the Bank's inflation targeting framework (www.bot.or.th).

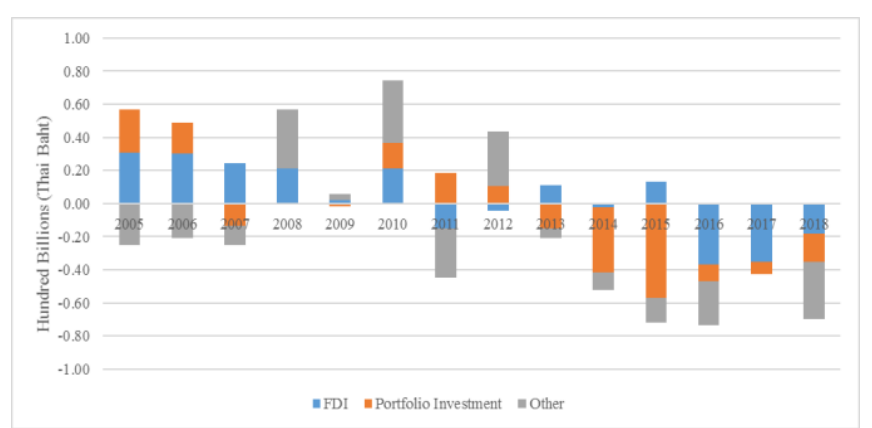

Fig. 1. Capital Flow in Thailand during 2005-2018.

The previous empirical studies have extensively investigated the relationship between capital flows and exchange rate but most of them are focusing on developed countries [1], [2]. Even though some literature recently documents the impact of capital flow on exchange rate in emerging countries, they only analyze either type of capital flows or direction of flows [3]-[6]. However, the studies of exchange rate and capital flow of Thailand are scant and completely inconclusive. This paper empirically investigates the relationship between capital flows and real effective exchange rate of Thai Baht. The paper mainly contributes to examine the impact of asymmetric capital flows, decomposing the net capital flows into the period of capital inflows and the period of capital outflows. The Nonlinear Autoregressive Distributed Lags (NARDL), proposed by Shin et al. [7], is applied and accommodates for the impact of long-run and short-run asymmetry of capital flows on Thailand's real effective exchange rate. The NARDL is the extension of ARDL which is recently used in capturing the long-run relationship between capital flows and exchange rate [8], [9]. The monthly data for the period 2005M1 to 2018M12 is used for analyze in this paper.

The unit root test indicates a mixture of series with unit root and stationary for series in log level whereas all series are stationary when the first difference is performed. The Granger causality test confirms that real effective exchange rate of Thai Baht can be explained by net capital flow. Specifically, the capital inflow and the capital outflow have different impact on real exchange rate of Thai Baht. An increase in capital inflow tends to appreciate Thai Baht. The NARDL model indicates the existence of long-run relationship between capital inflow and real effective exchange rate of Thai Baht but no long-run relationship between capital outflow and real effective exchange rate. 
These results might suggest the policy maker to satisfy the exchange rate policy regarding to the asymmetry of capital flow.

The rest of the paper is structured as follows. Section II reviews the literature. The data and methodology are presented in section III. Section IV analyses the empirical results and section $\mathrm{V}$ concludes.

\section{LITERATURE REVIEW}

Even though the previous literature provides mixed evidence on the relationship between capital flow and exchange rate, this paper mainly focuses on the impact of capital flow on exchange rate. The flood of capital inflow could push the exchange rate appreciate and weaken the countries' competitiveness [10], [11]. On the other hand, the large capital outflow possibly lowers the economic growth prospects and makes the policy makers have more concerns about the exchange rate policy.

The impact of the capital flows on the real exchange rates of single country like Mexico is studied by Ibarra [8]. They use quarterly data from the years 1988-2008 (the period after the free trade open in 1998 and before the 2008 crisis) and apply the Autoregressive Distributed Lag (ARDL) model. They find that the inflows of all types of capital flows (direct investment and foreign portfolio investment) cause the appreciations in the real exchange rate of the Mexican peso. Furthermore, they also observe that foreign direct investments are less volatile than other types of capital inflows which imply that foreign direct investment inflows can be used as the tool by policy makers to make the real exchange rate less volatile than other types of capital inflows. There is the study that also covers the emerging and developing countries which their economic growth issue is very important. Combes et al [9] use the data from 42 countries during 1980-2006 and separate capital flows into public inflows and private inflows. Private capital flows are the aggregation of direct investments, investments in portfolio, loans and private transfers. By implementing the Pooled Mean Group Estimator technique, which helps to observe the impact of capital flows on real exchange rates both in the long term and the short-term, they find that all types of capital flows have the relationship with real exchange rates' appreciations. The private sector's capital flows in portfolio investment have the greatest effect on the appreciations of currencies. Portfolio investments show the biggest impact on the appreciation which are almost seven times that of foreign direct investment or bank loans. The research also shows that the real exchange rate will be stronger from the capital flows in countries that employ flexible exchange rate regime.

Not all the countries have experienced the same degree of volatility causing by the capital flows. Kodongo and Ojah [3] study the relationship between real exchange rates and the capital flows of portfolio investments in four African countries, including Egypt, Morocco, Nigeria and South Africa. Using monthly data during the years 1997-2009, they employ Granger causality and Vector Autoregressions technique and find that the dynamic relationship between capital flows of portfolio investment and the real exchange rates are country-dependent and time-varying. Especially capital flows of portfolio investment of African countries are non-persistent and highly volatile than that of other African countries.

However, there are mixed results among the research about the positive and negative impact of capital flows on exchange rate volatility. On one hand, Reinhart and Smith [12] show that the increase in capital flows raise exchange volatilities. On the other hand, Agenor [11] find that capital flows help improve liquidity, productivity and risk sharing between countries. So, the later studies decompose the capital flows and investigate the impact of each type of capital flows on the exchange rate volatilities.

By decomposing the capital flows into FDI (foreign direct investment), FPI (foreign portfolio investment) and other financial assets investment (bank loans), Jongwanich and Kohpaiboon [4] discover that the effect of capital flows on real exchange rates of 9 countries (Indonesia, Thailand, Singapore, Korea, India, Malaysia, Philippines, Taiwan and China in Asia during period 2000-2009) have the different level of appreciations for each type of capital flows on the real exchange rates. FDI and other investment (bank loans) provide faster speed of real exchange rate appreciations than foreign direct investment inflows. They also find that the capital outflows have greater effect on real exchange rate than capital outflows for all types of flows.

Certain research provides the evidence of the benefit and harms of capital flows to the exchange rate volatility. Al-Abri and Baghestani [5] focuses on the issue of exchange rate volatility of ASEAN countries (China, India, Malaysia, Singapore, South Korea, Indonesia, Philippines and Thailand) during the year 1980-2011. Employing time series and panel data approaches, the results suggest that the increase in capital flows can help decrease exchange rate volatility for China, India, Malaysia, Singapore and South Korea. However, they find the opposite impact for exchange rate volatility for Indonesia, the Philippines and Thailand.

In order to investigate the different impact of equity and bond portfolio flows. Caporale et al. [6] classify capital flows into two categories and study the impact of each type of capital flows on exchange rate volatility of 7 ASEAN countries including India, Indonesia, Pakistan, Philippines, South Korea, Taiwan and Thailand (China, Hong Kong and Malaysia are excluded because of their fixed exchange rate regime). They use monthly data from the years 1993-2015 and employ the GARCH Model and Markov Switching specification model. The results of the study show that 1) capital flows from equity markets from ASEAN countries except Philippines affect the exchange volatility at high level. 2) The bond inflows in ASEAN countries have low impact on exchange rate volatility except Philippines. Therefore, capital controls are effective tools that help stabilize the foreign exchange market.

Although the previous empirical literature has extensively investigated the relationship between capital flows and exchange rate but most of them documents the impact of capital flow on exchange rate by analyzing either type of capital flows or direction of flows [3]-[6]. Furthermore, the study of exchange rate and capital flow in Thailand is still limited. The fluctuations of capital flow and exchange rate 
during the past 10 years also underline the importance of revisiting this relationship.

\section{DATA AND MeThodology}

Since the frequency of data is a limitation of many previous papers studying Thailand's capital flow and exchange rate [4], [5], [9] most of them use yearly or semi-annually data for studies. This paper uses the monthly data for all variables during the period of 2005-2018. Then, 168 observations are obtained in the specification. The higher-frequency data lead to more precise estimators, according to higher degree of freedom [13]. The variables in this paper include the real effective exchange rate of Thai Baht (REER) and the net capital flow (NETCF). Control variables, the industrial production index (IPI) and the terms of trade (TOT), are also included in the model. The industrial production index (IPI) is represented as an indicator of relative productivity in the tradable sector while the terms of trade (TOT) indicate the ratio of export's price to import's price. The REER, NETCF, and TOT are obtained from the Bank of Thailand whereas the IPI is collected from the Office of Industrial Economics, Thailand.

In terms of methodology, this paper starts with the unit root testing for all variables. Augmented Dickey-Fuller is applied. Then, the Granger Causality test is used to confirm that NETCF causes REER and how much of the current REER can be explained by past values of REER and then to examine whether adding lagged values of NETCF can improve the explanation. The equation for testing the Granger Causality is set as follows

$\operatorname{REER}_{\mathrm{t}}=\pi_{11}+\pi_{12} \mathrm{REER}_{\mathrm{t}-1}+\pi_{13} \mathrm{NETCF}_{\mathrm{t}-1}+\pi_{14} \mathrm{REER}_{\mathrm{t}-2}+$ $\pi_{15} \mathrm{NETCF}_{\mathrm{t}-2}+\pi_{16} \mathrm{REER}_{\mathrm{t}-3}+\pi_{17} \mathrm{NETCF}_{\mathrm{t}-3}+\pi_{18} \mathrm{REER}_{\mathrm{t}-4}+$ $\pi_{19} \mathrm{NETCF}_{\mathrm{t}-4}+v_{\mathrm{t} 1}$

$\mathrm{NETCF}_{\mathrm{t}}=\pi_{21}+\pi_{22}$ REER $_{\mathrm{t}-1}+\pi_{23} \mathrm{NETCF}_{\mathrm{t}-1}+\pi_{24} \mathrm{REER}_{\mathrm{t}-2}+$ $\pi_{25} \mathrm{NETCF}_{\mathrm{t}-2}+\pi_{26} \mathrm{REER}_{\mathrm{t}-3}+\pi 27 \mathrm{NETCFt}_{-3}+\pi_{28} \mathrm{REER}_{\mathrm{t}-4}+$ $\pi_{29} \mathrm{NETCF}_{\mathrm{t}-4}+\mathrm{v}_{\mathrm{t} 2}$

Lastly, the Nonlinear Autoregressive Distributed Lags (NARDL) developed by Shin et al. [7] is adopted to measure the impact of capital flows of Thailand's real exchange rate index. The NARDL model is the extension of ARDL model, which previous papers such as Ibarra [8] and Combes et al. [9] use for analyzing the impact of capital flow on the real effective exchange rate. The benefits of the NARDL are capturing long-run asymmetry and cointegrating relationship among variables, with the advantage that the variables in the cointegrating relationship can be either $\mathrm{I}(0)$ or $\mathrm{I}(1)$. The first step of NARDL is decomposing the NETCF into the period of capital inflows and capital outflows as in equation (3).

$$
\mathrm{NETCF}_{\mathrm{t}}=\mathrm{NETCF}_{0}+\mathrm{CF}_{\mathrm{t}}^{+}+\mathrm{CF}_{\mathrm{t}}^{-}
$$

where

$\mathrm{NETCF}_{0}$ is net capital flow at time 0

$\mathrm{CF}_{\mathrm{t}}^{+}$is the summation of capital inflow, which is calculated by $\sum_{\mathrm{j}=1}^{\mathrm{t}} \mathrm{CF}_{\mathrm{j}, \mathrm{t}}^{+}=\sum_{\mathrm{j}=1}^{\mathrm{t}} \max \left(\mathrm{CF}_{\mathrm{j}, \mathrm{t}}^{+}, 0\right)$.
$\mathrm{CF}_{\mathrm{t}}^{-}$is the summation of capital outflow, which is calculated by $\sum_{\mathrm{j}=1}^{\mathrm{t}} \mathrm{CF}_{\mathrm{j}, \mathrm{t}}^{-}=\sum_{\mathrm{j}=1}^{\mathrm{t}} \max \left(\mathrm{CF}_{\mathrm{j}, \mathrm{t}}^{-}, 0\right)$.

Therefore, $\mathrm{CF}_{\mathrm{t}}^{+}$represents the period of capital inflows and $\mathrm{CF}_{\mathrm{t}}^{-}$represents the period of capital outflows.

Next, the NARDL equation is set up in equation (4).

$$
\begin{aligned}
& \Delta \text { REER }_{\mathrm{t}}=\alpha_{1}+\alpha_{2} \text { REER }_{\mathrm{t}}+\alpha_{3} \mathrm{CF}_{\mathrm{t}}^{+}+\alpha_{4} \mathrm{CF}_{\mathrm{t}}^{-}+\alpha_{5} \mathrm{IPI}_{\mathrm{t}} \\
& +\alpha_{6} \text { TOT }_{t}+\sum_{i=1}^{p} \theta_{1, i} \Delta \text { REER }_{t-i}+\sum_{i=1}^{p} \theta_{2, i} \Delta \mathrm{CF}_{t-i}^{+} \\
& +\sum_{\mathrm{i}=1}^{\mathrm{p}} \theta_{3, \mathrm{i}} \Delta \mathrm{CF}_{\mathrm{t}-\mathrm{i}}^{-}+\sum_{\mathrm{i}=1}^{\mathrm{p}} \theta_{4, \mathrm{i}} \Delta \mathrm{IPI} \mathrm{t}-\mathrm{i}+\sum_{\mathrm{i}=1}^{\mathrm{p}} \theta_{5, \mathrm{i}} \Delta \mathrm{TOT}_{\mathrm{t}-\mathrm{i}} \\
& +\varepsilon{ }_{t}
\end{aligned}
$$

where $\Delta$ is the change of variables and $\varepsilon_{t}$ is the error term. $p$ is number of lag length. We choose the automatic selection using the Akaike Information Criterion (AIC) with a maximum of 4 lags of both the REER and all regressors. Then, long-run coefficients of capital inflow and capital out flow are calculated as equation (5) and (6).

The long-run coefficient of capital inflow $\left(\beta^{+}\right)=-\frac{\alpha_{3}}{\alpha_{2}}$

The long-run coefficient of capital outflow $\left(\beta^{-}\right)=-\frac{\alpha_{4}}{\alpha_{2}}$

Finally, the bounds testing is employed to investigate whether the model in equation (4) contains a long-run relationship between the REER and all regressors. The null hypothesis is that there is no long-run relationship. Pesaran et al. [14] provide critical values as bounds for the cases where the regressors are a mixture of $\mathrm{I}(0)$ and $\mathrm{I}(1)$.

\section{EMPIRICAL RESULTS}

Table I presents the results of unit root tests for all variables. The null hypothesis for the ADF test is that series contains a unit root. The test includes both a constant and trend. Lags are automatically chosen based on Schwarz Information Criterion (SIC), with a maximum of 13 lags. The results indicate a mixture of series with unit root and stationary for series in log level. For example, REER, $\mathrm{CF}^{+}$, $\mathrm{CF}^{-}$, and TOT have unit root whereas NETCF and IPI are stationary. However, all series are stationary when the first difference is performed.

TABLE I: THE UNIT RoOT TEST

\begin{tabular}{lrrrr}
\hline \hline & \multicolumn{2}{c}{ Log level } & \multicolumn{2}{c}{$1^{\text {st }}$ difference $(\Delta)$} \\
\hline \hline Variables & t-Statistics & Prob. & t-Statistics & Prob. \\
\hline REER & -3.2155 & 0.0850 & -10.6970 & 0.0000 \\
NETCF & -11.6974 & 0.0000 & -9.6401 & 0.0000 \\
$\mathrm{CF}^{+}$ & -0.4158 & 0.9863 & -10.0234 & 0.0000 \\
$\mathrm{CF}^{-}$ & 0.4827 & 0.9992 & -5.6650 & 0.0000 \\
IPI & -4.1143 & 0.0073 & -12.7789 & 0.0000 \\
TOT & -2.3244 & 0.4181 & -9.9203 & 0.0000 \\
\hline \hline
\end{tabular}


Next, the Granger Causality test is performed to confirm that capital flow causes real effective exchange rate of Thailand. The results in Table II shows that only net capital flow and capital outflow tend to cause the change in real effective exchange rate of Thai Baht at $10 \%$ significant level. Meanwhile, the capital inflow does not cause the change in real effective exchange rate and vice versa. The result in Table II confirms that real effective exchange rate of Thai Baht can be explained by capital flow. Moreover, the capital inflow and the capital outflow have different impact on real exchange rate of Thai Baht.

TABLE II: CAUSALITY TEST

\begin{tabular}{lrr}
\hline \hline Causality test & Chi-sq & Prob. \\
\hline$\Delta$ REER $>>$ NETCF & 4.0556 & 0.3985 \\
NETCF $>>$ REER & 8.2582 & 0.0826 \\
$\Delta \mathrm{REER}>\Delta \mathrm{CF}^{+}$ & 6.2908 & 0.1785 \\
$\Delta \mathrm{CF}^{+}>>\Delta \mathrm{REER}^{-}$ & 2.8877 & 0.5768 \\
$\Delta \mathrm{REER}^{>}>\Delta \mathrm{CF}^{-}$ & 2.1524 & 0.7077 \\
$\Delta \mathrm{CF}^{-}>>\mathrm{REER}^{-}$ & 9.3366 & 0.0532 \\
\hline \hline
\end{tabular}

Using the AIC with a maximum of 4 lags, the lag length in the equation (4) is automatically chosen as NARDL $(3,0,1,3,1)$. The findings in Table III reveal that an increase in capital inflow $(\mathrm{CF}+)$ has a positive impact on Thailand's real effective exchange rate (an appreciation of Thai Baht) with $10 \%$ significant level. This empirical result is consistent to the assumption and many previous empirical results. An increase in capital outflow (CF-) also has a negative impact on Thai Baht (a depreciation of Thai Baht) but is not statistically significant. In addition, the industrial production index (IPI) is a key economic variable that explains the movement of real effective exchange rate. The $10 \%$ increase in IPI has a statistically negative impact on Thai Baht to decrease by approximately $4.68 \%$, which is consistent to the previous research such as Jongwanich and Kohpaiboon [4] and Combes et al. [9]. Meanwhile, the terms of trade (TOT)'s coefficient shows negative sign, which is to be expected but not statistically significant.

\begin{tabular}{|c|c|c|}
\hline Variable & Coefficient & Prob. \\
\hline Constant $\left(\alpha_{1}\right)$ & -6.0478 & 0.2544 \\
\hline $\operatorname{REER}\left(\alpha_{2}\right)$ & 0.1251 & 0.0032 \\
\hline $\mathrm{CF}^{+}\left(\alpha_{3}\right)$ & 0.0000 & 0.0506 \\
\hline $\mathrm{CF}^{-}\left(\alpha_{4}\right)$ & -0.0000 & 0.1237 \\
\hline $\operatorname{IPI}\left(\alpha_{5}\right)$ & -0.0468 & 0.0930 \\
\hline $\operatorname{TOT}\left(\alpha_{6}\right)$ & -0.0098 & 0.7752 \\
\hline$\Delta \operatorname{REER}_{\mathrm{t}-1}\left(\theta_{1,1}\right)$ & 0.0750 & 0.3400 \\
\hline$\Delta \operatorname{REER}_{\mathrm{t}-2}\left(\theta_{1,2}\right)$ & -0.0130 & 0.8683 \\
\hline$\Delta \operatorname{REER}_{\mathrm{t}-3}\left(\theta_{1,3}\right)$ & -0.2844 & 0.0002 \\
\hline$\Delta \mathrm{CF}^{+}\left(\theta_{2,1}\right)$ & 0.0000 & 0.6523 \\
\hline$\Delta \mathrm{CF}^{-}\left(\theta_{3,1}\right)$ & 0.0000 & 0.7130 \\
\hline$\Delta \mathrm{CF}_{\mathrm{t}-1}^{-}\left(\theta_{3,2}\right)$ & 0.0000 & 0.1686 \\
\hline$\Delta \operatorname{IPI}\left(\theta_{4,1}\right)$ & 0.0597 & 0.0700 \\
\hline$\Delta \operatorname{IPI}_{\mathrm{t}-1}\left(\theta_{4,2}\right)$ & -0.0269 & 0.4077 \\
\hline$\Delta \operatorname{IPI}_{\mathrm{t}-2}\left(\theta_{4,3}\right)$ & 0.0991 & 0.0013 \\
\hline$\Delta \operatorname{IPI}_{\mathrm{t}-3}\left(\theta_{4,4}\right)$ & 0.0990 & 0.0012 \\
\hline$\Delta \operatorname{TOT}\left(\theta_{5,1}\right)$ & -0.0199 & 0.8755 \\
\hline$\Delta \operatorname{TOT}_{\mathrm{t}-1}\left(\theta_{5,2}\right)$ & 0.2315 & 0.0782 \\
\hline
\end{tabular}

Using equation (5) and (6), the long-run coefficient of capital inflow $\left(\beta^{+}\right)$equals to 0.0000 , with the $10 \%$ significant level. This indicates the long-run relationship between capital inflow and real effective exchange rate of Thai Baht. Meanwhile, the long-run coefficient of capital outflow $\left(\beta^{-}\right)$ equals to 0.0000 , without statistically significant.

TABLE IV: BOUNDS TESTING

\begin{tabular}{lcccc}
\hline \hline Test Statistic & Value & Signif. & $\mathrm{I}(0)$ & $\mathrm{I}(1)$ \\
\hline \multirow{3}{*}{ F-Statistic } & Asymptotic: $\mathrm{n}=1000$ & & \\
$\mathrm{k}$ & 17.9000 & $10 \%$ & 2.20 & 3.09 \\
& 4 & $5 \%$ & 2.56 & 3.49 \\
& & $1 \%$ & 3.29 & 4.37 \\
Actual Sample Size & Finite Sample: $\mathrm{n}=80$ & & \\
& 164 & $10 \%$ & 2.30 & 3.22 \\
& & $5 \%$ & 2.69 & 3.70 \\
& & $1 \%$ & 3.60 & 4.79 \\
\hline \hline
\end{tabular}

Finally, the bounds testing is used to investigate the existence of level relationship under the null hypothesis of no level relationship. The results in Table IV confirm that the level relationship between real effective exchange rate of Thai Baht and all variables exists.

\section{CONCLUSION}

The capital flow has been one of the economic factors developing Thai economy for the past 10 years. Thailand has net capital inflow during 2005-2010 but has net capital outflow after relaxing foreign exchange regulations in 2012. The large net capital outflow after 2012 has been accelerating because of Thai political crisis. Thailand has been experienced net capital outflow up to the present. Even though there are some literature documents the impact of capital flow on Thai Baht, most of them only study type of capital flow or direction of flow. This paper attempts to apply the new model called "NARDL" to capture the asymmetry of capital flow on exchange rate. The net capital flow of Thailand is decomposed into the period of capital inflow and the period of capital outflow. Three main empirical findings are revealed that (1) the real effective exchange rate of Thai Baht can be explained by net capital flow (2) an increase in capital inflow has a positive impact on Thailand's real effective exchange rate with $10 \%$ significant level. Also, an increase in capital outflow also has a negative impact but is not statistically significant (3) the long-run relationship between capital inflow and real effective exchange rate of Thai Baht exists. These results are implication for policy makers in Thailand in conducting the exchange rate policy in the future.

\section{CONFLICT OF INTEREST}

The authors declare no conflict of interest.

\section{AUTHOR CONTRIBUTIONS}

Termprasertsakul conducted the research, analyzed the data, and wrote the paper. Seree-amnoui collect the data. All authors had approved the final version. 


\section{REFERENCES}

[1] R. Brooks, H. Edison, M. S. Kumar, and T. Sløk, "Exchange rates and capital flows," European Financial Management, vol. 10, pp. 511-533, Aug. 2004.

[2] G. Siourounis. (August 2004). Capital flows and exchange rates: An empirical analysis. London Business School IFA Working Paper No. 400. [Online]. Available: https://ssrn.com/abstract $=572025$

[3] O. Kodongo and K. Ojah, "The dynamic relation between foreign exchange rates and international portfolio flows: Evidence from Africa's capital markets," International Review of Economics and Finance, vol. 24, pp. 71-87, 2012.

[4] J. Jongwanich and A. Kohpaiboon, "Capital flows and real exchange rates in emerging Asian countries," Journal of Asian Economics, vol. 24, pp. 138-146, 2013.

[5] A. Al-Abri and H. Baghestani, "Foreign investment and real exchange rate volatility in emerging Asian countries," Journal of Asian Economics, vol. 37, pp. 34-47, 2015.

[6] G. M. Caporale, F. M. Ali, F. Spagnolo, and N. Spagnolo, "International portfolio flows and exchange rate volatility in emerging Asian markets," Journal of International Money and Finance, vol. 76, pp. 1-15, 2017.

[7] Y. Shin, B. Yu, and M. Greenwood-Nimmo, "Modelling asymmetric cointegration and dynamic multipliers in an ARDL framework," SSRN Working Paper 1807745, 2013.

[8] C. A. Ibarra, "Capital flows and real exchange rate appreciation in Mexico," World Development, vol. 39, no. 12, pp. 2080-2090, 2011.

[9] J. L. Combes, T. Kinda, and P. Plane, "Capital flows, exchange rate flexibility, and the real exchange rate," Journal of Macroeconomics, vol. 34, no. 4, pp. 1034-1043, 2012.
[10] G. Calvo, L. Leiderman, and C. Reinhart, "Inflows of Capital to developing countries in the 1990s," Journal of Economic Perspectives, vol. 10 , pp. 123-139, 1993.

[11] P. R. Agenor, "Capital inflows, external shocks, and the real exchange rate," Journal of International Money and Finance, vol. 17, pp. 713-740, 1998.

[12] C. M. Reinhart and R. T. Smith, "Temporary controls on capital inflows," Journal of International Economics, vol. 57, no. 2, pp. 327-351, 2002.

[13] M. M. Dacorogna, R. Gencay, U. A. Muller, R. B. Olsen, and O. V. Pictet, An Introduction to High-Frequency Finance, Elsevier Inc., 2001, ch. 1, pp. 1-9.

[14] M. H. Pesaran, Y. Shin, and R. J. Smith, "Bounds testing approaches to the analysis of level relationships," Journal of Applied Econometrics, vol. 16, no. 3, pp. 289-326, 2001.

Copyright (C) 2020 by the authors. This is an open access article distributed under the Creative Commons Attribution License which permits unrestricted use, distribution, and reproduction in any medium, provided the original work is properly cited (CC BY 4.0).

Santi Termprasertsakul is currently a finance lecturer at Faculty of Business Administration for Society, Srinakharinwirot University, Bangkok, Thailand. He received his Ph.D. degree in finance from University of Essex, England. His research is focusing on international finance.

Prin Seree-Amoui earned M. S. in finance from Thammasat University in 2010 and is currently studying Ph.D. in business administration, finance major at Thammasat University Bangkok Thailand. 